\title{
Maturity Level On Computer-Based Accounting Systems: The Case of Indonesian Small Medium Enterprises
}

\author{
M. Noor Ardiansah \\ Politeknik Negeri Semarang \\ mnardiansah@polines.ac.id,and +62-812-282-160-3 \\ Indah Anisykurlillah \\ Universitas Negeri Semarang \\ indah_anis@mail.unnes.ac.id and +62-812-282-173-3
}

\begin{abstract}
This study aims to provide the empirical facts of the maturity level of computer-based accounting systems adopted by small and medium enterprises (SMEs) in Indonesia. This study was motivated by the limited research on the antecedent of adoption of computer-based accounting systems in SMEs. A survey conducted to SMEs in Semarang using questionnaire. The data was analyzed using correlation test. The results show the maturity level of the SMEs accounting system is at the third level (defined), which means that the accounting system development activities have been determined but are not yet optimal. Key maturity activities that are related significantly are planning and organization, business process management, risk management, and problem management, as well as system standardization and measurement. The results of this study contribute to the government to create a strategy for increasing adoption by strengthening the SMEs system maturity.
\end{abstract}

Keywords: computer-based accounting system, level of adoption, maturity level of the system, SMEs

\section{INTRODUCTION}

Recently, the development of information technology (IT) has significantly changed the business (Elliott, 1992) and makes IT as a competitive advantage (Porter \& Millar, 1985). Therefore, various business entities have used IT as a resource to increase productivity, product quality, service satisfaction, and create confidence for consumers as well as to make relevant decisions (Matrane, Talea, \& Okar, 2015). IT has influenced unexceptionally form and substance of business, as well as techniques in accounting recording (Ardiansah, 2011). The accounting system is needed to capture not only financial but also non-financial data to support more relevant financial information (Brecht \& Martin, 1996). The accounting system 
must be able to produce reliable, accurate, and timely information that is relevant to making a decision (Ismail, Abdullah, \& Tayib, 2003).

SMEs have adopted a computer-based accounting system (CBAS) model because it is considered essential and determines the survival and success of the business (Louadi, 2009). SMEs also need to increase the competitiveness in price and product quality for them to compete with large companies (Ardiansah, 2011). Furthermore, SMEs has experienced a high failure rate (Ballantine, Levy, \& Powell, 1998) because of their inability to influence market prices by changing output levels (Storey \& Cressy, 1996). SMEs has a small market share relying heavily on a small number of customers (Storey \& Cressy, 1996). Thus, to be able to compete successfully, SMEs needs to have an information system that can make them to prepare reports more timely and gives them information for making business decisions (Ismail et al., 2003).

The urgency and existence of SMEs in economic development of a developing country have received considerable attention in the number of literatures. SMEs lead an essential role because of their significant contributions in fulfilling employment and income distribution in many countries (Ardiansah, 2011; Seyal, Rahim, \& Rahman, 2000; Wijewardana, 2018). Moreover, the critical contribution of SMEs in the Indonesian economy as a developing country is clear. Among others, 52.4 million SMEs absorbed 67\% of the workforce, contributed $63.5 \%$ to gross domestic product (GDP) and $18.4 \%$ to total exports (BPS, 2018).

Several studies have been conducted to identify factors that influence the level of IT used by SMEs (e.g. Davis, Bagozzi, \& Warshaw, 1989; DeLone \& McLean, 1992; DeLone, 1981; Gatautis \& Neverauskas, 2005; Hakim \& Nurkamid, 2017; Lees, 1987; Montazemi, 1988; Oswari, Suhendra, \& Harmoni, 2008; Poorangi, Khin, Nikoonejad, \& Kardevani, 2013; Raymond, 1985; Shahrum et al., 1996; Widjaja \& Matitaputty, 2018). Some of the identified 
factors have influence on the IT maturity adoption by SMEs, such as organizational characteristics (size and business age), managerial aspects, employee knowledge, consultant support, government support, information intensity, and external pressure (Oswari, Suhendra, \& Harmoni, 2008; Widjaja \& Matitaputty, 2018).

Most of the studies on implementation of IT in SMEs focus on the use and application of IT in business organizations. Even though it is still limited, several studies have attempted to identify the purpose of IT of accounting systems in SMEs. The findings however do not examine relationship between the indicators of adoption and IT used in the accounting system and the factors that influence its use (e.g., Daniel \& Wilson, 2002; Duschinsky \& Dunn, 1998; King \& He, 2006; Noor Azizi \& Malcolm, 2007). This study aims at providing empirical evidence of the CBAS maturity model for Indonesian SMEs in especially Semarang which is a mixture of urban and rural areas. Some research questions include how identification and level of adoption of CBAS in SMEs and maturity level of CBAS in SMEs. The results of this study provide important indicators of readiness of SMEs. The future challenges in relation with IT are adoption which can accelerate preparation of timely financial reports and contribute to the design of comprehensive computerized accounting systems.

\section{LITERATURE REVIEW}

SMEs are business units managed by community and families. Data published by the Ministry of Cooperatives and SMEs show that at the end of 2016 the number of SMEs was 58.2 million units and continues to increase. Absorption of labour reached $97.04 \%$ of the total employment in Indonesia. In Central Java, the number of SMEs at the end of 2016 was 80,853 units (BPS, 2018). 
SMEs have a strategic role in developing businesses, but some complex problems constrain their development (Sarosa, 2012). Indonesian SMEs carry out their business activities using traditional methods. On the other hand, companies use sophisticated IT to compete each other since IT considerably plays an essential role in improving quality of economic decision making (Haryani, 2012). Small business managers and cooperatives state that they do not have knowledge in accounting and many of them do not understand the importance of recording and bookkeeping for business continuity (Al-Fahim, Wan Jusoh, \& Abideen, 2016). Small entrepreneurs see that the accounting process is not necessary to be applied. Similar conditions happens oin SMEs in Semarang. Most of them have not organized well and used accounting in managing their businesses (Li, 2008; Tambunan, 2009; Widyaningdyah, 2014).

As a profit organization, SMEs are expected to achieve profitability through the value of product or service quality. The globalized trade, investment, and dynamic technology force SMEs to be ready for competing in the future (Matrane et al., 2015). Therefore, among other factors, financial resources and the use of technology are relevant, which must be available and adequate, cost-effective, and used properly (Louadi, 2009). In recent market competition, SMEs need to recognize that IT has the potential to increase productivity, quality, and performance - areas that are important for their survival and success. SMEs also need nonfinancial information, such as price changes, market trends, and customer behavior to survive and grow (Chenhall \& Morris, 1986).

Various government programs and incentives including application of technology and building competency of human resources have supported the development of SMEs. The adoption and effectiveness of IT adoption among SMEs are still the issue the government concerns greatly. Ismail et al. (2003) and Shahrum et al. (1996) found that IT adoption among SMEs was only $51 \%$ in which SMEs used computers for accounting and financial purposes. 
Duschinsky and Dunn (1998) found that $86 \%$ of small companies established in the U.K. had a computerized accounting system.

The low adoption rate is an essential issue because SMEs make up the majority of manufacturing companies in Indonesia. One possible explanation for it is less attention of most SMEs owners on IT (Agwu \& Murray, 2015). Understanding of IT technology could be still relatively low (Alonso Mendo \& Fitzgerald, 2005) or they were not aware of incentives offered by supporting institutions.

The progress of IT has created a new generation of computerized accounting excluded from the high-end system such as ERP (Enterprises Resource Planning). An ERP system is an integrated software package designed to provide complete integration of the business system for organizations processing and all related data (Awa, Ukoha, \& Emecheta, 2016; Lai, Lai, \& Lowry, 2016). ERP systems will strengthen company's strategic position with the availability of information that can support management decision making processes. Even though several fully integrated software is available, SMEs however tend to use computers for primarily supporting operational or administrative jobs and not for making strategic decisions (Chen, Windasari, \& Pai, 2014; Daniel \& Wilson, 2002; Debreceny, Gray, Jun-Jin Ng, Siow-Ping Lee, \& Yau, 2005; Duschinsky \& Dunn, 1998; Raymond \& MagnenatThalmann, 1982; J.Y.L. Thong \& Yap, 1995). The popular software modules used by SMEs are basic accounting modules such as ledgers, accounts payable, accounts receivable, and payroll. The findings show that SMEs have not fully utilized the available technology offered by the latest accounting software systems to produce strategic information.

CBAS is classified into two main categories: low-end and high-end systems. The distinguished characteristics are easeness and speed of information. Information is taken from the accounting database, the quantity of information that can be stored in the database, the intensity of use, and ease of modification and customization (Spivak \& Honig, 1997). 
Moreover, Xiao, Dyson, and Powell (1996) found that the aspects determining accounting system's central are the level of computerization, the type of IT-based systems, the kind of IT applied, workstations for staff, and years of using IT. Other results showed that most UK companies have some IT applications that are integrated into the accounting system and the others have a separate computerized accounting system (Chen \& Williams, 1998). They also found that the level of computerization was higher in large companies than in small and medium-sized companies.

The findings of Levy and Powell (1998) and Powell (1996) previously confirmed that the size of the company was a determinant of the level of sophistication (e.g., DeLone, 1981; Lees, 1987; Thong, 1999). Hunton and Beeler (1997) found that firm size was significantly negatively but weakly correlated with the level of IT used in accounting. They suggested that differences were possibly caused by lower capital and risk barriers due to dramatic decreases in IT costs. Companies of all sizes can benefit from the latest IT development. Another possible explanation is that midsize companies may have developed from small companies. Otherwise, their managers may have limited capabilities in fr example time and education to appreciate the benefits of using an integrated accounting system. Xiao et al. (1996) subsequently found that $80 \%$ of companies were almost or fully satisfied with their IT-based accounting system. Nearly $90 \%$ stated that their IT application objectives were entirely or nearly satisfied. Shahrum et al. (1996) have confirmed the findings of Xiao et al. (1996). Duschinsky and Dunn (1998) stated that almost $96 \%$ of established small companies in the U.K. had a computerized accounting system. Those companies used the system for invoices recording, managing the report, payroll, and marketing.

However, another research conducted by Chen and Williams (1998) resulted in different directions. They found that only $55 \%$ of small-scale enterprises or agricultural handicrafts located in rural areas in East England had used microcomputer systems. This fact 
indicates that geographical location and type of business sector might have a significant impact on the use of IT among SMEs. Besides that, the decrease in computer hardware and software costs, availability and ease of use of computers, and better software packages could cause an increase in the number of computer accounting installations in smaller and mediumsized organizations (Thong, 1999).

The use of IT among SMEs still shows conflicting facts. Small businesses in a country do not show a similar pattern of adoption. This fact is because SMEs is not fully regulated and do not need timely financial reporting. It has pressure compared to large companies in which IT adoption depends on the type of business, IT management awareness, and IT benefits. The nature of business that is less complicated has made SMEs to show a greater tendency to buy commercial accounting packages. That is much cheaper than internal and external packages tailored to the needs (Gray, 1991). Shahrum et al. (1996) confirmed this finding to Indonesian SMEs. Generally, SMEs have experienced in leading their business, but are lack in the information systems knowledge. Therefore, most SMEs always turn to external experts for help. Unfortunately, external experts may have very little understanding on the nature of the company's business. Thong and Yap (1995) proposed a concerted effort to enhance cooperation between SMEs and external expertise to help SMEs in obtaining technology transfer. Matrane et al. (2015) revealed the findings that IT adoption maturity in the case of CBAS concept was determined by (1) business management, (2) risk management, (3) operations management, (4) incident management, and (5) problem management in implementing IT adoption. These are the indicators of achievement of maturity that will place each SME in a group according to the level of implementation, development, and capability in developing a better business strategy (Matrane et al., 2015; Rajendran \& Elangovan, 2012). 
The structure of our maturity model is built upon the following four dimensions:

1) Maturity level dimension:

(a) Level 1 (initial): there is no process area, and a process is chaotic.

(b) Level 2 (defined) is the level where implementation processes are documented, standardized, and integrated into a standard implementation process for the organization.

(c) Level 3 (managed): process and activities are controlled and managed based on quantitative models and tools.

2) Maturity Model for Information Security Management.

3) Maturity Model for Project Management.

4) Governance of Information System.

The maturity model for Information System gives the possibility for managers of organizations to see where it stands and how it can improve its information system. Thus, it provides a methodology for an organization to develop an improvement roadmap to its Information System. The new maturity model for information security management is composed of five distinct phases that encompass historical practices and future aspirations. It is called the five management $(5 \mathrm{M})$ of information security.

(1.) Level 1: Business Management. This level is for synthesizing the key objectives and resources that must be protected to achieve them. This level allows management to integrate the security into all the processes and structures and to support external requirements (regulatory compliance, and others) and internal (business lines, policies).

(2.) Level 2: Risks Management. This level is for quantifying the actual level of risk and bringing closure to the acceptable level by the company. This level helps to identify, order risk, and control projects to reduce risk. 
(3.) Level 3: Operations Management. This level is for evaluating the daily running of security operations and their ability to provide an optimum ratio cost /security. This level aligns processes and controls policies to reduce the rate of conversion of risk in incidents.

(4.) Level 4: Incidents Management. This level is for assessing the ability of the company to respond to security incidents for ensuring that the level of risk tolerance is never exceeded. This level allows detecting, analysing, processing, and communicating security events to minimize the effects and costs of resolution. It is vital to be able to detect and analyse very quickly for taking appropriate measures to limit its impact.

(5.) Level 5 Problems Management. This level is the unknown cause of one or more incidents, often identified as a result of multiple similar events. The objective of Problem Management is to minimize the impact of problems of security on the organization. Problem Management plays a vital role in the detection and providing solutions to problems (workarounds \& known errors) and prevents their reoccurrence.

\section{METHODS}

The population of this study was Small and Medium Enterprises in Semarang that are identified as using IT in their business. Based on the data from the Office of Cooperative and SMEs in Semarang, their amount was 608. The sample was carried out using purpose random sampling, i.e. the managers of SMEs that were registered in the economic census of the Central Bureau of Statistics in 2015 and were especially in financial and service industries. The number were 120 small companies in Semarang. The financial services sector is considered information sensitive (Chen et al., 2014), and so it is expected to provide the most 
comprehensive use of IT because of the presence of all primary business functions (Raymond \& Thalmann, 1982).

The questionnaire was divided into three main parts. The first part is general background of the company: company background and ownership, legal status, type of industry, year established, number of employees, and total income for the previous fiscal year. The second part investigates the adoption and extent of CBAS used. Five IT adoption maturity instruments were taken from Matrane et al. (2015):

1. Business management, including indicators of the definition of business objectives, the level of business risk, and essential business resources,

2. risk management, including indicators of understanding internal and external barriers, identification of fraud, and the classification of resources with high values;

3. operations management, including priority work indicators based on risk, increased awareness of security, the need for supervision and ratification of the system;

4. incident management, including indicators of identification of events, priorities for business impacts, and reporting on business managers;

5. problem management, including indicators of neglect of incidents that have occurred, minimizing the effects of the problem, initiating events that might be repeating.

The electronic mailed questionnaire and direct filling one were submitted to the SMEs owner for getting a higher collection rate. Mailed questionnaires returned within a specific date were processed and analyzed further. The respondents were asked to give their perception on the quality of the computerized accounting system adopted in connection with the content, accuracy, format, and timeliness. This dimension provided evidence about the extent to which the output of CBAS is considered useful for the end-user. In this study, endusers were the leaders of sampled SMEs who use the output of accounting systems to make business decisions. The Responses were on a five-point Likert. A non-response bias test was 
conducted to determine the difference in the respondents' answers before and after the date to return the questionnaire. Testing the level of adoption of CBAS for five instruments was used Spearman Correlation for alpha 5\%, with higher values indicating high intensity.

\section{RESULTS AND DISCUSSION}

Of 120 companies engaged in the financial and service industries, the questionnaires collected in the arranged time was 98 or response rate of $81.67 \%$. No questionnaires returned after the arranged time, so there was no need for a non-response bias test. The description of the respondents' answers are presented in the table 1.

Table 1. Statistics Descriptions of Respondents

\begin{tabular}{|c|c|c|c|c|}
\hline \multirow{3}{*}{ Indicators Variables } & \multicolumn{4}{|c|}{ Value Description Maturity } \\
\hline & \multirow{2}{*}{ Minimal } & \multirow{2}{*}{ Maximal } & \multirow{2}{*}{ Average } & Standard \\
\hline & & & & Deviation \\
\hline PO 1 & 1,00 & 4,00 & 3,08 & 0,176 \\
\hline $\mathrm{PO} 2$ & 2,00 & 4,00 & 3.34 & 0,059 \\
\hline PO 3 & 2,00 & 4,00 & 3,39 & 0,056 \\
\hline $\mathrm{PO} 4$ & 2,00 & 4,00 & 3,43 & 0,061 \\
\hline ME 1 & 1,00 & 4,00 & 3,04 & 0,181 \\
\hline ME 2 & 2,00 & 4,00 & 3,39 & 0,256 \\
\hline ME 3 & 2,00 & 4,00 & 3,39 & 0,156 \\
\hline $\mathrm{BM}$ & 2,00 & 4,00 & 3,39 & 0,167 \\
\hline $\mathrm{RM}$ & 1,00 & 4,00 & 3,04 & 0,057 \\
\hline $\mathrm{OM}$ & 2,00 & 4,00 & 3,42 & 0,390 \\
\hline $\mathrm{IM}$ & 1,00 & 5,00 & 3,34 & 0,170 \\
\hline $\mathrm{PM}$ & 2,00 & 4,00 & 3,47 & 0,055 \\
\hline SI & 2,00 & 4,00 & 3,46 & 0,157 \\
\hline $\mathrm{SZ}$ & 2,00 & 4,00 & 3,63 & 0,256 \\
\hline $\mathrm{CO}$ & 2,00 & 5,00 & 3,64 & 0,050 \\
\hline CI & 2,00 & 4,00 & 3,31 & 0,152 \\
\hline
\end{tabular}

Sources: primary data processing 
Based on the table 1, some findings can be described. First, the minimum limit of 1 is on four variables (PO1, ME1, R.M., I.M.). This indicates conditions in which there are no supporting documents, no processes that show appropriate performance, and no activity to develop determined innovations. The minimum limit of 2 indicates conditions in which there are some supporting documents or processes that show adequate performance, and activities to develop determined innovations that are routine operations. Second, the maximum limit of 5 is on two variables (I.M., CO) which indicates conditions: there are documents, processes, and development activities that are well managed, widely known and implemented as good practices, and implementation constraints are managed well. The minimum limit mode is 4 on different conditions (PO1, ME1, R.M., I.M.) with a value of five in conditions not yet widely known and implemented well and routinely. The three average values range more than 3 (R.M., PM, CO) with a standard deviation of less than 0.6, which indicates a relatively low limit so that the condition of maturity shows. There are documents, processes, and development activities that are very well managed. The situation is widely known and implemented as good practices, but there are still implementation constraints that are needed to be managed properly.

Subsequent findings are related to the computerized quality of accounting systems adopted in connection with the content, accuracy, format, and timeliness of the conditions of SMEs system maturity. These dimensions provide evidence of the extent to which the output of CBAS is considered useful for the end-user. Tests on the aspects of CBAS on the condition of SMEs' system maturity using correlation with the Spearman Rho are presented in table 2. 
Table 2. Correlation of System and Dimension of CBAS

\begin{tabular}{|c|c|c|c|c|c|c|c|c|c|c|c|c|}
\hline Var & $\mathrm{PO}$ & $\mathrm{ME}$ & $\mathrm{BM}$ & $\mathrm{RM}$ & $\mathrm{PM}$ & IM & MM & ST & $\mathrm{SZ}$ & $\mathrm{CO}$ & $\mathrm{CI}$ & MS \\
\hline $\mathrm{PO}$ & 1,000 & 0,305 & 0,466 & 0,305 & 0,712 & 0,492 & 0,657 & 0,241 & 0,223 & 0,398 & 0,756 & 0,609 \\
\hline $\mathrm{ME}$ & & 1,000 & $-0,50$ & 0,246 & 0,674 & 0,304 & 0,876 & 0,641 & 0,871 & 0,451 & 0,431 & 0,348 \\
\hline $\mathrm{BM}$ & & & 1,000 & 0,291 & $-0,38$ & 0,691 & $-0,57$ & 0,539 & 0,761 & 0,765 & 0,566 & 0,627 \\
\hline $\mathrm{RM}$ & & & & 1,000 & 0,447 & 0,591 & 0,991 & 0,601 & 0,545 & 0,551 & 0,811 & 0,806 \\
\hline PM & & & & & 1,000 & 0,871 & 0,765 & 0,403 & 0,076 & 0,546 & 0,762 & 0,402 \\
\hline $\mathrm{IM}$ & & & & & & 1,000 & 0,657 & 0,567 & 0,362 & 0,771 & 0,234 & 0,505 \\
\hline $\mathrm{M}$ & & & & & & & & 0,387 & & & & \\
\hline $\mathrm{M}$ & & & & & & & 1,000 & & 0,221 & 0,547 & 0,761 & 0,867 \\
\hline $\mathrm{TS}$ & & & & & & & & 1,000 & 0,341 & 0,331 & 0,541 & 0,668 \\
\hline SZ & & & & & & & & & 1,000 & 0,268 & 0,165 & 0,770 \\
\hline $\mathrm{CO}$ & & & & & & & & & & 1,000 & 0,817 & 0,520 \\
\hline CI & & & & & & & & & & & 1,000 & 0,230 \\
\hline MS & & & & & & & & & & & & 1,000 \\
\hline
\end{tabular}

Sources: primary data processing

Notes:

P.O.: planning and organization, ME: monitoring and evaluation, B.M.: business management, R.M.: risk management, PM: operational management, MI: incident management, MM: problem management, S.T.: standardization, S.Z.: size, CI: continuous development, MS: CBAS system maturity

Table 2 shows several things. First, there are several variables of the level of adoption of CBAS which correlate above 0.60 with the CBAS maturity variables. They are variables of planning and organization $(\mathrm{P} . \mathrm{O} .=0.609)$, business management $(\mathrm{MB}=0.627)$, risk management $(\mathrm{MR}=0.806)$, problem management $(\mathrm{MM}=867)$, standardization $(\mathrm{S} . \mathrm{T} .=$ 0.668) and measurement (U.K. $=0.770)$. Second, a correlation of more than 0.6 at a significance of 0.05 indicates a high perceptional relationship between the CBAS adoption level variable to the CBAS maturity dimension. Third, the highest correlation of the CBAS adoption level variable to the CBAS maturity dimension is reflected in the problem management variable $(0.806)$. These facts show that the very high maturity dimension of CBAS is related to problem management perceived and faced by SMEs. 


\section{Discussion}

CBAS maturity level shows the condition on the third level. That means CBAS has documents, processes, and development activities that are well managed, widely known, and implemented. As good practices, there are still implementation constraints that need to be adequately managed. This condition is supported by further findings that some conditions of CBAS adoption are highly correlated with the CBAS maturity level. Constraints still need to be controlled at maturity level 3 . The situation shows that system planning and organization towards business, business management patterns, concern for risk management in information technology-based business are severe concern for CBAS maturity level.

The results also show some indicators influencing the CBAS adoption which are planning and organization, business patterns, risk management, business problems, standardization of documentation and reporting, and measurement of business data. They must be clearly defined according to SMEs classification. High relationships in planning and organization are not followed by a monitoring and evaluation (M.E.) process and high operational management (MO), which SMEs’ suspicions do not prioritize.

A presumption is that SMEs run the business with lacks of knowledge in information systems, especially their operational processes. Therefore, most SMEs always turn to external experts help in implementing CBAS. Unfortunately, the external experts may have very little understanding on the nature of the company's business. Thong and Yap (1995) and Thong, Yap, and Raman, (1996) proposed a concerted effort to enhance cooperation between SMEs and external expertise to help SMEs to obtain technology transfer.

These findings alter the results of the study of Matrane, Talea, and Okar (2015) revealing findings that IT adoption maturity in the case of CBAS concept was determined by (1) business management, (2) risk management, (3) operations management, (4) incident management, and (5) problem management in implementing IT adoption. The determinants 
in this study that our findings focus on security management are business management, risk management, and problem management. The determinants show high correlation variables related to the maturity level of CBAS. SMEs are aware of the need for security and the importance of risk on CBAS while the business is running.

The development of CBAS adoption for SMEs in Semarang is directed not only to use systems and information technology but also to better manage and control business-based management planning and to organize useful resources, business management based on business risk management, and to handle functional business problems and data standards consistent business base. This fact supports the findings of Honig (1999) in which CBAS is not only about the ease and speed of information taken from the accounting database (the information quantity can be stored in the database, the intensity of use, and ease of modification and customization (Spivak \& Honig, 1997)) but also is patterned as a corporate resource planning (ERP) model. An ERP system is an integrated software package designed to provide complete integration of business systems and processing information and all related data (Venkatraman \& Fahd, 2016).

\section{CONCLUSIONS AND IMPLICATIONS}

Based on the description of the results, it can be concluded that (1) identification of the level of adoption of CBAS shows that SMEs in Semarang has adopted CBAS sufficiently, evidenced by the minimum of 1 (existing) maturity level that indicates that there is an activity for development CBAS although it is still document related activity and not optimal, (2) the maturity level of CBAS taken by SMEs is on an average level of 3 (defined) which shows that the processes and activities have been documented, development has been carried out but there are still obstacles that need to be adequately managed, and (3) key maturity activities 
that are significantly related to CBAS adoption level are planning and organization, business management, risk management, problem management, standardization, and measurement.

Some suggestions for SMEs in Semarang are they need to pay more attention on readiness for adopting CBAS for future challenges. This condition accelerates the adopting preparation, which is divided into planning and organization, business management, risk management, problem management, standardization, and measurement of a business database. Semarang Cooperative and SMEs Office needs more massive programs and incentives to help overcoming the obstacles faced in the use of information and communication technology in the development of CBAS.

\section{REFERENCES}

Agwu, E. M., \& Murray, P. J. (2015). Empirical Study of Barriers to Electronic Commerce Uptake by SME's in Developing Economies. International Journal of Innovation in the Digital Economy, 6(2), 1-19. https://doi.org/10.4018/ijide.2015040101

Al-Fahim, N. H., Wan Jusoh, W. J., \& Abideen, A. (2016). An Examination Factors Influencing the Intention to Adopt Internet Banking Among SMES in Yemen: Using an Extension of The Technology Acceptance Model (TAM). Journal of Internet Banking and Commerce, 2l(Special Issue 5). Retrieved from https://www.scopus.com/inward/record.uri?eid=2-s2.0-

84995543638\&partnerID=40\&md5=807e5d12855995be35897376c971e524

Alonso Mendo, F., \& Fitzgerald, G. (2005). A Multidimensional Framework for SME e-Business Progression. Journal of Enterprise Information Management, 18(6), 678-696. https://doi.org/10.1108/17410390510628382

Ardiansah, M. N. (2011). Pengaruh Karakteristik Koperasi Terhadap Permintaan Jasa Audit Eksternal: Studi Empiris Koperasi Di Kota Semarang. Jurnal Informasi, Perpajakan, Akuntansi, Dan Keuangan Publik, 6(2), 71-82. https://doi.org/10.25105/jipak.v6i2.4483

Awa, H. O., Ukoha, O., \& Emecheta, B. C. (2016). Using TOE Theoretical Framework to Study the Adoption of ERP Solution. Cogent Business and Management, 3(1). https://doi.org/10.1080/23311975.2016.1196571

Ballantine, J., Levy, M., \& Powell, P. (1998). Evaluating Information Systems in Small and Medium-Sized Enterprises: Issues and Evidence. European Journal of Information Systems, 7(4), 241-251. https://doi.org/10.1057/palgrave.ejis.3000307

BPS. (2018). Potensi UKM Provinsi Jawa Tengah. Semarang. Retrieved from 
https://www.bps.go.id/subject/35/usaha-mikro-kecil

Brecht, D. H. ., \& Martin, M. P. (1996). Accounting information systems: The challenge of extending their scope to business and information strategy. Accounting Horizons, 10(4), 1622.

Chen, J.-C., \& Williams, B. C. (1998). The impact of electronic data interchange (EDI) on SMEs: Summary of eight British case studies. Journal of Small Business Management, 36(4), 68.

Chen, J. K. C., Windasari, N. A., \& Pai, R. (2014). Exploring E-readiness on E-commerce adoption of SMEs: Case study South-East Asia. In IEEE International Conference on Industrial Engineering and Engineering Management (pp. 1382-1386). https://doi.org/10.1109/IEEM.2013.6962637

Chenhall, R. H., \& Morris, D. (1986). The Impact of Structure, Environment, and Interdependence on the Perceived Usefulness of Management Accounting Systems. Source: The Accounting Review, 61(1), 16-35. Retrieved from http://www.jstor.org/stable/247520\%5Cnhttp://www.jstor.org/page/info/about/policies/terms. jsp

Daniel, E., \& Wilson, H. (2002). Adoption intentions and benefits realised: A study of ecommerce in UK SMEs. Journal of Small Business and Enterprise Development, 9(4), 331348. https://doi.org/10.1108/14626000210450522

Davis, F. D., Bagozzi, R. P., \& Warshaw, P. R. (1989). User Acceptance of Computer Technology: A Comparison of Two Theoretical Models. Management Science, 35(8), 9821003. https://doi.org/10.1287/mnsc.35.8.982

Debreceny, R., Gray, G. L., Jun-Jin Ng, J., Siow-Ping Lee, K., \& Yau, W.-F. (2005). Embedded Audit Modules in Enterprise Resource Planning Systems: Implementation and Functionality. Journal of Information Systems, 19(2), 7-27. https://doi.org/10.2308/jis.2005.19.2.7

DeLone, William H.; McLean, E. R. (1992). Information systems success: The quest for the dependent variable. Information Systems Research, 3(1), 60-95. https://doi.org/10.5267/j.uscm.2014.12.002

DeLone, W. H. (1981). Firm Size and the Characteristics of Computer Use. Proceedings of the International Conference on Information Systems, 5(4), 327-329.

Duschinsky, P., \& Dunn, P. (1998). Competitive advantage from IT.

Elliott, R. K. (1992). The Third Wave Breaks on The Shores of Accounting. Accounting Horizons, 6(2), 61-73.

Gatautis, R., \& Neverauskas, B. (2005). E-commerce Adoption in Transition Economies: SMEs Perspectives in Lithuania Categories and Subject Descriptors General Terms Management. ICEC. Xi'an, China.

Gray, G. L. (1991). Accounting Information System Selection in Small Organizations: 
Incongruences between accounting Accounting Professionals. Journal of Information Systems, 5(1), 17-35.

Hakim, M. M., \& Nurkamid, M. (2017). Model Adopsi Ukm Di Kudus Terhadap ECommerce. Simetris: Jurnal Teknik Mesin, Elektro Dan Ilmu Komputer, 8(1), 339-344. https://doi.org/10.24176/simet.v8i1.974

Haryani, E. (2012). Accounting System for Small Business in Indonesia ( Case Study Convection Business in Tingkir Lor Village ). Journal of Arts, Science and Commerce, 2(April 2012), 104-112. Retrieved from www.researchersworld.com

Honig, S. A. (1999). The Changing Landscape of Computerized Accounting Systems. The CPA Journal, 69(5), 14-21.

Hunton, J. E., \& Beeler, J. D. (1997). Effects of User Participation in Systems Development: A Longitudinal Field Experiment. MIS Quarterly, 21(4), 359. https://doi.org/10.2307/249719

Ismail, N. A., Abdullah, S. N., \& Tayib, M. (2003). Computer-Based Accounting Systems: The Case of Manufacturing-Based Small and Medium Enterprises in the Northern Region of Peninsular Malaysia. Jurnal Teknologi, 39(1), 19-36. https://doi.org/10.11113/jt.v39.473

King, W. R., \& He, J. (2006). A Meta-Analysis of the Technology Acceptance Model. Information and Management, 43(6), 740-755. https://doi.org/10.1016/j.im.2006.05.003

Lai, V. S., Lai, F., \& Lowry, P. B. (2016). Technology Evaluation and Imitation: Do They Have Differential or Dichotomous Effects on ERP Adoption and Assimilation in China? Journal of Management Information Systems, 33(4), 1209-1251. https://doi.org/10.1080/07421222.2016.1267534

Lees, J. D. (1987). Successful Development of Small bBusiness Information Systems. Journal of Systems Management, 38(9), 32--39.

Levy, M., \& Powell, P. (1998). SME Flexibility and the Role of Information Systems. Small Business Economics, 11(2), 183-196. https://doi.org/10.1023/A:1007912714741

Li, X. (2008). An empirical examination of factors affecting adoption of an online direct sales channel by small and medium-sized enterprises. ProQuest Dissertations and Theses. Kent State University. https://doi.org/10.1002/asia.201100711

Louadi, M. El. (2009). The Relationship Among Organization Structure, Information Technology and Information Processing in Small Canadian Firms. Canadian Journal of Administrative Sciences, 15(2), 180-199. https://doi.org/10.1111/j.1936-4490.1998.tb00161.x

Matrane, O., Talea, M., \& Okar, C. (2015). Towards A New Maturity Model for Information System. 2015 International Journal of Computer Science Issues, 4(6), 71-78.

Montazemi, A. R. (1988). Environment Satisfaction in the Context of the Small Business. Factors Affecting Information Satisfaction in the Context of the Small Business Environment, $12(2), 239-256$.

Noor Azizi, I., \& Malcolm, K. (2007). Factors influencing the alignment of accounting information systems in small and medium sized Malaysian manufacturing firms. Journal of 
Information Systems and Small Business, 1(1-2), 1-20. Retrieved from https://ojs.deakin.edu.au/index.php/jissb/article/view/1

Oswari, T., Suhendra, E. S., \& Harmoni, A. (2008). Model Perilaku Penerimaan Teknologi Informasi: Pengaruh Variabel Prediktor, Moderating Effect, Dampak Penggunaan Teknologi Informasi Terhadap Produktivitas dan Kinerja Usaha Kecil. In Kommit (Vol. 1, pp. 20-21).

Poorangi, M. M., Khin, E. W. S., Nikoonejad, S., \& Kardevani, A. (2013). E-commerce adoption in Malaysian small and medium enterprises practitioner firms: A revisit on Rogers' model. Anais Da Academia Brasileira de Ciencias, 85(4), 1593-1604. https://doi.org/10.1590/0001-37652013103512

Porter, M. E. ., \& Millar, V. E. (1985). How information gives you competitive advantage. Harvard Business Review, 64(3), 149-160.

Powell, P. (1996). The extent, mode and quality of IT use in accounting. L of Applied Management Studies, 5(1), 143-158.

Rajendran, R., \& Elangovan, N. (2012). Response of Small Enterprises to the Pressures of ERP Adoption. International Journal of Enterprise Information Systems, 8(1), 28-50. https://doi.org/10.4018/jeis.2012010103

Raymond, L. (1985). Organizational Characteristics and MIS Success in the Context of Small Business. MIS Quarterly, 9(1), 37. https://doi.org/10.2307/249272

Raymond, L., \& Magnenat-Thalmann, N. (1982). Information Systems in Small Business: Are They Used in Managerial Decisions? American Journal of Small Business, 6(4), 20-26. https://doi.org/10.1177/104225878200600405

Sarosa, S. (2012). Adoption of Social Media Networks by Indonesian SME: A Case Study. Procedia Economics and Finance, 4, 244-254. https://doi.org/10.1016/S22125671(12)00339-5

Seyal, A. H., Rahim, M. M., \& Rahman, M. N. A. (2000). An Empirical Investigation of Use of Information Technology among Small and Medium Business Organizations: A Bruneian Scenario. The Electronic Journal of Information Systems in Developing Countries, 2(1), 117. https://doi.org/10.1002/j.1681-4835.2000.tb00014.x

Shahrum, H. ., Soa'ad, S. S. ., Engku, A. B. ., Kamran, S. ., Sabri, A. ., \& Zurni, O. (1996). IT Adoption among the Small and Medium Enterprises in the Northern Region of Peninsular Malaysia. Research Report for IRPA Project. Sintok.

Spivak, W., \& Honig, S. (1997). PC-based Client-server Accounting Systems. The CPA Journal, 67(11), 14.

Storey, D. J., \& Cressy, R. (1996). Small Business Risk: A Firm and Bank Perspective.

Tambunan, T. (2009). Export-Oriented Small and Medium Industry Clusters in Indonesia. Journal of Enterprising Communities: People and Places in the Global Economy, 3(1), 2558. https://doi.org/10.1108/17506200910943661 
Thong, J.Y.L., \& Yap, C. S. (1995). CEO Characteristics, Organizational Characteristics and Information Technology Adoption in Small Businesses. Omega, 23(4), 429-442. https://doi.org/10.1016/0305-0483(95)00017-I

Thong, James Y.L. (1999). An integrated model of information systems adoption in small businesses. Journal of Management Information Systems, 15(4), 187-214. https://doi.org/10.1080/07421222.1999.11518227

Thong, James Y.L., Yap, C. S., \& Raman, K. S. (1996). Top Management Support, External Expertise and Information Systems Implementation in Small Businesses. Information Systems Research, 7(2), 248-267. https://doi.org/10.1287/isre.7.2.248

Venkatraman, S., \& Fahd, K. (2016). Challenges and Success Factors of ERP Systems in Australian SMEs. Systems, 4(2), 20. https://doi.org/10.3390/systems4020020

Widjaja, A., \& Matitaputty, S. (2018). Empowerment of Small Medium Enterprises through Student Participatory Action Research in Implementation of Accounting Information System. SHS Web of Conferences, 59, 01002. https://doi.org/10.1051/shsconf/20185901002

Widyaningdyah, A. U. (2014). Adopsi Sistem Informasi Akuntansi Pada Usaha Kecil Dan Menengah: Sudahkah Selaras? Studi Empiris Pada Usaha Kecil Dan Menengah Di Surabaya Dan Sekitarnya. Jurnal Keuangan Dan Perbankan, 11(1), 82-101.

Wijewardana, W. P. (2018). Determinants of Accounting System In Small and Medium Enterprise. In he 5th IBSM Inte rna tional Confe rence on Business, Mana gement and Accounting (pp. 609-620). Hanoi: University of Hanoi.

Xiao, Z. Z., Dyson, J. R., \& Powell, P. L. (1996). The impact of information technology on corporate financial reporting: A contingency perspective. British Accounting Review, 28(3), 203-227. https://doi.org/10.1006/bare.1996.0015 